\title{
The ever increasing diversity of begomoviruses infecting non-cultivated hosts: new species from Sida spp. and Leonurus sibiricus, plus two New World alphasatellites
}

\author{
C.G. Ferro' ${ }^{1}$, J.P. Silva1 ${ }^{1}$, C.A.D. Xavier ${ }^{1}$, M.T. Godinho ${ }^{1}$, A.T.M. Lima1,3 ${ }^{1,3}$ T.B. Mar ${ }^{1}$, D. Lau² \& \\ F.M. Zerbini ${ }^{1}$ \\ 1 Dept de Fitopatologia/BIOAGRO and National Research Institute for Plant-Pest Interactions, Universidade Federal de Viçosa, Viçosa, MG 36570-900, Brazil \\ 2 Embrapa Trigo, Rodovia BR285 km 294, Passo Fundo, RS 99050-970, Brazil \\ 3 Present address: Instituto de Ciências Agrárias, Universidade Federal de Uberlândia, Uberlândia, MG 38400-902, Brazil
}

\section{Keywords}

Begomovirus; geminivirus: recombination; plant virology; satellite DNA.

\section{Correspondence}

F.M. Zerbini, Dept de Fitopatologia/BIOAGRO and National Research Institute for Plant-Pest Interactions, Universidade Federal de Viçosa, Viçosa, MG 36570-900, Brazil.

Email: zerbini@ufv.br

Received: 3 March 2016; revised version accepted: 3 August 2016; published online: 20 January 2017

doi:10.1111/aab.12329

\begin{abstract}
Begomoviruses (whitefly-transmitted, single-stranded DNA plant viruses) are among the most damaging pathogens causing epidemics in economically important crops worldwide. Besides cultivated plants, many weed and wild hosts act as virus reservoirs where recombination may occur, resulting in new species. The aim of this study was to further characterise the diversity of begomoviruses infecting two major weed genera, Sida and Leonurus. Total DNA was extracted from samples collected in the states of Rio Grande do Sul, Paraná and Mato Grosso do Sul during the years 2009-2011. Viral genomes were enriched by rolling circle amplification (RCA), linearised into unit length genomes using various restriction enzymes, cloned and sequenced. A total of 78 clones were obtained: 37 clones from Sida spp. plants and 41 clones from Leonurus sibiricus plants. Sequence analysis indicated the presence of six bipartite begomovirus species and two alphasatellites. In Sida spp. plants we found Sida micrantha mosaic virus (SiMMV), Euphorbia yellow mosaic virus (EuYMV), and three isolates that represent new species, for which the following names are proposed: Sida chlorotic mottle virus (SiCMoV), Sida bright yellow mosaic virus (SiBYMV) and Sida golden yellow spot virus (SiGYSV), an Old World-like begomovirus. L. sibiricus plants had a lower diversity of begomoviruses compared to Sida spp., with only Tomato yellow spot virus (ToYSV) and EuYMV (for the first time detected infecting plants of the genus Leonurus) detected. Two satellite DNA molecules were found: Euphorbia yellow mosaic alphasatellite, for the first time detected infecting plants of the genus Sida, and a new alphasatellite associated with ToYSV in L. sibiricus. These results constitute further evidence of the high species diversity of begomoviruses in non-cultivated hosts, particularly Sida spp.
\end{abstract}

\section{Introduction}

The family Geminiviridae comprises plant viruses with one or two genomic components of circular, single-strand DNA (ssDNA) encapsidated in geminate particles (Brown et al., 2012). The family is divided into seven genera (Becurtovirus, Begomovirus, Curtovirus, Eragrovirus, Mastrevirus, Topocuvirus and Turncurtovirus) according to the type of insect vector, host range, genome organisation and phylogeny (Brown et al., 2012; Varsani et al., 2014). The genus Begomovirus is the largest in the family and includes mono- and bipartite viruses transmitted by Bemisia tabaci (Hemiptera: Aleyrodidae) to dicotyledonous plants (Brown et al., 2015).

Based on phylogenetic analysis and genomic features, begomoviruses are broadly divided into two groups: Old World (OW; Europe, Africa, Asia and Oceania) and New World (NW; the Americas) (Rybicki, 1994; Padidam et al., 1999; Paximadis et al., 1999). Begomoviruses in the New World are mostly bipartite (DNA-A and DNA-B), except for Tomato leaf deformation virus (ToLDeV), 
an indigenous NW monopartite virus (Melgarejo et al., 2013). The DNA-A contains genes involved in replication, encapsidation of viral progeny and suppression of host defenses (Rojas et al., 2005; Hanley-Bowdoin et al., 2013), and the DNA-B contains genes required for intraand intercellular movement in the plant, host range determination and suppression of host defenses (Rojas et al., 2005; Mahajan et al., 2011; Hanley-Bowdoin et al., 2013; Brustolini et al., 2015). The majority of the begomoviruses that occur in the OW are monopartite, with a genomic organisation similar to the DNA-A of bipartite viruses (Padidam et al., 1996; Mansoor et al., 2003) and the presence of an additional open reading frame (ORF) which partially overlaps the $c p$ gene, named $v 2$ in monopartite viruses or av2 in bipartite viruses. The V2/AV2 protein is involved in viral movement and gene silencing suppression (Rybicki, 1994; Padidam et al., 1996; Glick et al., 2008). Begomoviruses in the OW are generally associated with satellite DNA molecules (Zhou, 2013).

Brazil is a begomovirus diversity hotspot, with reports of their detection dating back to the 1950s (Costa \& Bennett, 1950; Costa, 1955). Begomoviruses are limiting factors for common bean and tomato production (Faria et al., 2000; Zerbini et al., 2005), and a large number of new species of tomato-infecting begomoviruses has been identified in the country (Ribeiro et al., 2003; Fernandes et al., 2006; Calegario et al., 2007; Ribeiro et al., 2007; CastilloUrquiza et al., 2008; Fernandes et al., 2008; Albuquerque et al., 2012). The advent of techniques for the unbiased amplification of circular DNA genomes (specially rolling circle amplification, RCA (Inoue-Nagata et al., 2004), created new possibilities for the discovery of novel begomoviruses, and also of divergent ssDNA viruses (Krenz et al., 2012; Loconsole et al., 2012; Basso et al., 2015).

Non-cultivated species of the families Asteraceae, Caparaceae, Euphorbiaceae, Fabaceae, Labiatae, Malvaceae, Solanaceae and Sterculiaceae have been reported as hosts of many begomoviruses in Brazil and in several other countries in the Americas (Frischmuth et al., 1997; Roye et al., 1997; Faria and Maxwell, 1999; Fernandes et al., 1999; Idris et al., 2003; Jovel et al., 2004; Assunção et al., 2006; Amarakoon et al., 2008; Castillo-Urquiza et al., 2008; Barbosa et al., 2009; Silva et al., 2011; Silva et al., 2012; Tavares et al., 2012; Barreto et al., 2013). There is evidence that some of these begomoviruses from noncultivated hosts can be transmitted to cultivated species by the insect vector and by grafting (Arnaud et al., 2007; Castillo-Urquiza et al., 2007; Cotrim et al., 2007; Silva et al., 2010; Barreto et al., 2013; Rocha et al., 2013; Ramos-Sobrinho et al., 2014), highlighting the need to investigate these plants as reservoirs of viral diversity and as a source of new viruses which may cause diseases in crops.

\section{Materials and methods}

During the years 2009 to 2011 , leaf samples from Sida spp. (Malvaceae) and Leonurus sibiricus (Lamiaceae) plants displaying symptoms of yellow mosaic and leaf distortion and/or infestation by $B$. tabaci were collected in the states of Rio Grande do Sul $(n=27)$, Paraná $(n=33)$ and Mato Grosso do Sul $(n=10)$. Total DNA was extracted from press-dried samples as described by Doyle $\&$ Doyle (1987). Full-length viral circular genomes were enriched by rolling-circle amplification (RCA) as described by Inoue-Nagata et al. (2004). Unit length genomes were excised with ApaI, BamHI, ClaI, EcoRI, HindIII, KpnI, SacI, SalI or SpeI and ligated into the pBLUESCRIPT-KS+ (pKS+) plasmid vector (Stratagene, San Diego, CA, USA), previously cleaved with the same enzyme. Viral inserts were sequenced commercially (Macrogen Inc., Seoul, South Korea) by primer walking. All genome sequences were organised to begin at the nicking site in the invariant nonanucleotide at the origin of replication (5'-TAATATT//AC-3').

Pairwise sequence comparisons were performed using Sequence Demarcation Tool (SDT) v.1.2 (Muhire et al., 2014) using the MUSCLE alignment option (Edgar, 2004). Multiple sequence alignments were obtained using the MUSCLE algorithm implemented in MEGA6 (Tamura et al., 2013). Phylogenetic analyses were performed with the sequences of the closest begomoviruses determined by BLASTn comparison of the clones generated in this study and the sequences deposited in Genbank, plus some begomovirus sequences of the New and Old World. Phylogenetic trees were constructed using Bayesian inference performed with MrBayes v. 3.0b4 (Ronquist \& Huelsenbeck, 2003), with the nucleotide substitution model selected by MrModeltest v. 2.2 (Nylander, 2004) in the Akaike Information Criterion (AIC). The analysis was run for 10 million generations, excluding the first 2000000 generations as burn-in. The trees were visualised in FigTree v.1.3.1 (tree.bio.ed.ac.uk/software/figtree/). Recombination analysis was performed with Recombination Detection Program (RDP) v.4.5.1 (Martin et al., 2010) using default settings and a Bonferroni-corrected $P$-value cutoff of 0.05 . The same data set used for the phylogenetic analysis was used for recombination analysis. Only those recombination events detected by more than four of the seven tests implemented in RDP were considered to be reliable.

\section{Results and discussion}

A total of 70 samples (43 Sida spp. samples, 27 L. sibiricus samples) were collected and 61 were preliminarily positive for the presence of a begomovirus, based on the 
detection of an approximately 2600-bp band after digestion of the RCA products with restriction enzymes (data not shown). A total of 78 clones were obtained: 37 clones from Sida spp. samples and 41 clones from L. sibiricus samples (Table 1; these include DNA-A, DNA-B and satellite DNA clones). BLASTn analysis and pairwise sequence comparisons indicated the presence of six begomovirus species and two alphasatellites (Table 1; Figs. S1 and S4).

Pairwise sequence comparisons of cloned genome sequences with those deposited in GenBank indicated that Sida micrantha mosaic virus (SiMMV) was the predominant begomovirus infecting Sida spp. plants. Out of 15 DNA-A clones obtained from this host, 10 correspond to SiMMV isolates, as well as 19 out of the 21 DNA-B clones (Table 1). The DNA-A sequences share $>96.3 \%$ nucleotide (nt) identity amongst themselves and $96.3 \%$ to $97.2 \%$ identity with SiMMV (accession number FN436003), and the DNA-B sequences share $>88.0 \% \mathrm{nt}$ identity amongst themselves and 89.1-93.3\% identity with SiMMV (FN436004) (Fig. S1). Bayesian phylogenetic trees based on either the DNA-A or DNA-B placed these isolates in a monophyletic branch together with SiMMV (Fig. 1).

Two DNA-A sequences (BR:Trm531.2:10 and BR:Caa691:10) obtained from Sida spp. samples \#531 and \#691 displayed $97.0 \%$ and $97.2 \%$ nt sequence identity to Euphorbia yellow mosaic virus (EuYMV; FJ619507), respectively (Table 1; Fig. S1). This virus has already been found infecting Sida santaremnensis in Minas Gerais (Tavares et al., 2012).

The Sida sample \#531 actually had a mixed infection. A virus representing a new species (BR:Trm531.1:10) based on the criteria of $<91 \%$ nt sequence identity for the DNA-A, recently updated by the Geminiviridae Study Group of the ICTV (Brown et al., 2015), was cloned from this sample, for which the name Sida chlorotic mottle virus ( $\mathrm{SiCMoV})$ is proposed. Pairwise sequence comparisons of the DNA-A sequence (2601 nt) with those deposited in GenBank indicated a maximum nt sequence identity of $81.5 \%$ with Tomato dwarf leaf virus (ToDfLV, JN564749) (Fig. S1). A DNA-B was detected in the sample but has not yet been cloned. SiCMoV is placed in a monophyletic branch with ToDfLV, Tomato chino La Paz virus (ToChLPV), Tomato leaf deformation virus (ToLDeV), Tomato golden mosaic virus (TGMV), Sida mosaic Bolivia virus 1 (SiMBoV1) and Abutilon mosaic Bolivia virus (AbMBoV; Fig. 1A). This close relationship is consistent with the pairwise sequence identity analysis and with previously reported data (Márquez-Martín et al., 2011; Medina \& Lambertini, 2012; Melgarejo et al., 2013). Interestingly, although no recombination events were detected for this virus, it clustered with viruses of the EuYMV group (including BR:Trm531.2:10 obtained from the same sample) in a $c p$ nt sequence tree, but with SiMBoV1, ToDfLV and Tomato yellow spot virus (ToYSV) in a rep nt sequence tree (Fig. S2), suggesting a recombinant origin. Mixed infections by different begomoviruses are common in non-cultivated hosts (García-Andrés et al., 2006; Alabi et al., 2008; Monde et al., 2010), facilitating recombination events among distantly related begomoviruses which may contribute to the frequent emergence of new species.

A virus corresponding to a second new species was cloned from the Sida spp. sample \#720 (BR:Tac720:10). Nucleotide sequence identity between the common regions (CR) of the DNA-A and DNA-B was $94.7 \%$, and the two components have identical iterons (TGGGG), indicating that they constitute a cognate pair. Both the DNA-A (2692 nt) and the DNA-B (2656 nt) show the highest nt sequence identity with SiMMV $(86 \%$ and $75.5 \%$, respectively; Fig. S1). The name Sida bright yellow mosaic virus (SiBYMV) is proposed for this new species. Analysis with the RDP4 program detected one strongly supported recombination event in the DNA-A, with SiMMV (FN436003) and an unknown virus as the putative parents (Table 2). Phylogenetic reconstruction based on the DNA-A placed this isolate in a monophyletic branch with SiMMV isolates, occupying a basal position in the clade (Fig. 1A). The recombination event has strong phylogenetic support: the rep nt sequence tree places BR:Tac720:10 in a monophyletic branch $(99 \%$ posterior probability) with the SiMMV isolates, while the $c p$ nt sequence tree places the isolate in a monophyletic branch (99\% posterior probability) with Abutilon mosaic Brazil virus (AbMBV, JF694480; Fig. S2). Phylogenetic analysis based on the DNA-B placed this isolate in a monophyletic branch with SiMMV, Tomato rugose mosaic virus (ToRMV, AF291706) and Tomato severe rugose virus (ToSRV, KC004086), occupying a basal position in the clade (Fig. 1B). One recombination event was detected, with BR:Tol1075:11 and Bean dwarf mosaic virus (BDMV, M88180) as the putative parents (Table 2). The recombination event has good phylogenetic support: BR:Tac720:10 groups with different begomoviruses in the $m p$ and $n s p$ nt sequence trees (Fig. S3). Recombination is a common event among geminiviruses (Padidam et al., 1999; Lefeuvre et al., 2009) and contributes greatly to their evolutionary potential and local adaptation (Harrison \& Robinson, 1999; Padidam et al., 1999; Berrie et al., 2001; Monci et al., 2002). A number of natural begomovirus recombinants have been responsible for severe diseases and great economic losses in cassava in East Africa (Zhou et al., 1997; Pita et al., 2001), tomatoes in Spain (Monci et al., 2002; García-Andrés et al., 2006; García-Andrés et al., 2007a,b), and cotton and okra in Pakistan (Zhou et al., 1998; Idris and Brown, 2002; Briddon et al., 2014). 


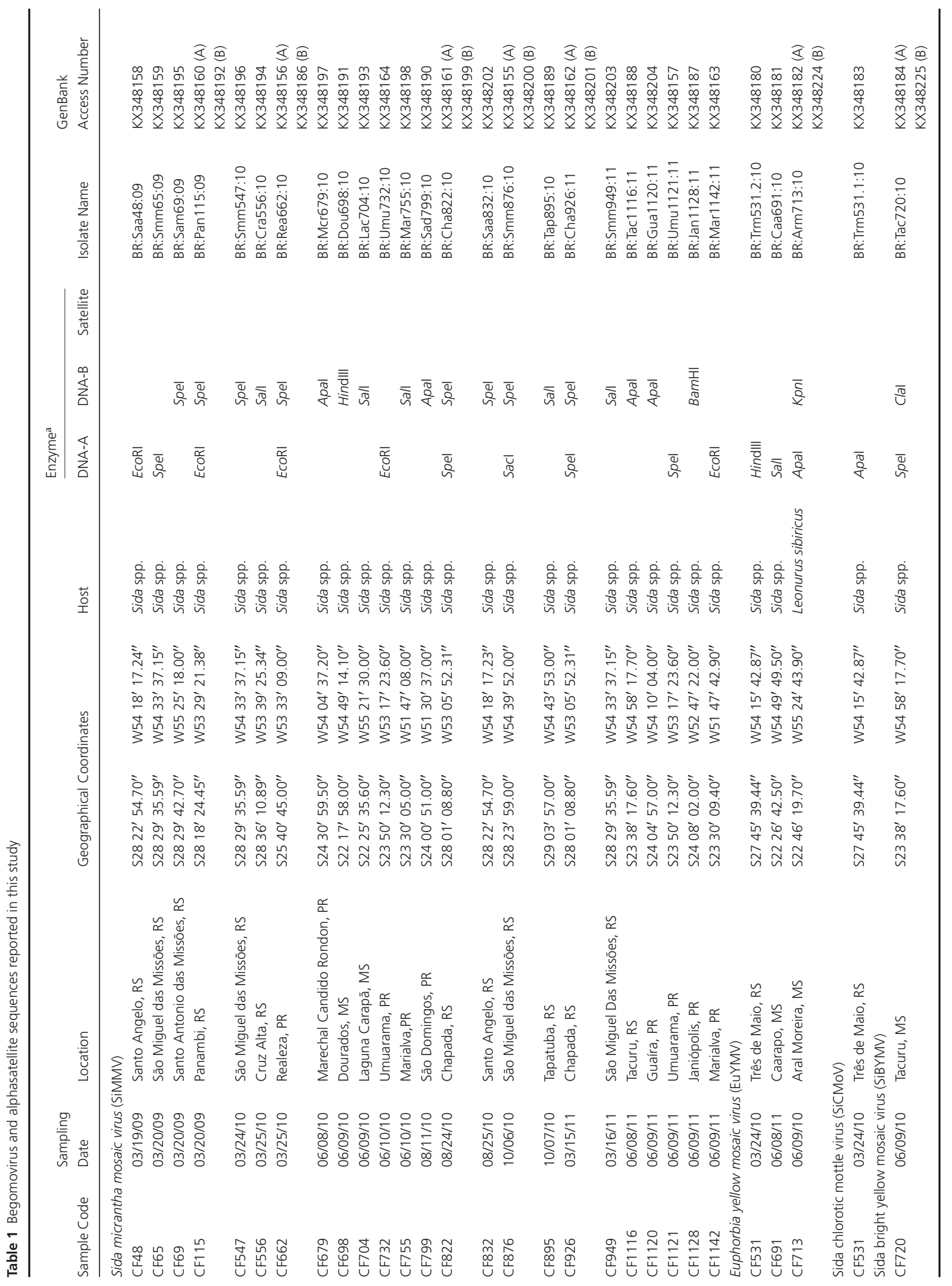


A

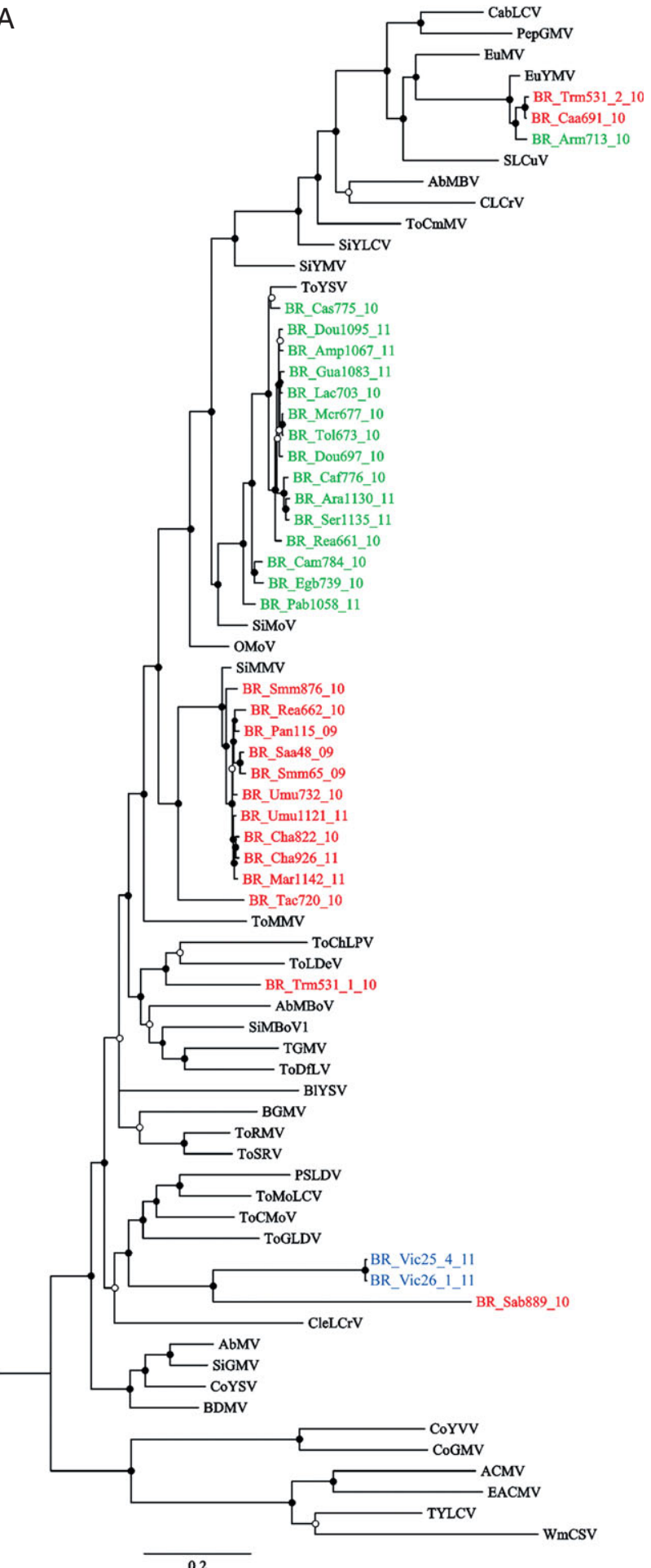

0.2

Figure 1 Bayesian phylogenetic trees based on the complete DNA-A (A) and DNA-B (B) nucleotide sequences of the begomoviruses obtained from Sida spp. (red) and Leonurus sibiricus plants (green) in this study plus begomoviruses from the New World and Old World (see Table S1 for full names and GenBank access numbers). BR:Vic25.4:11 and BR:Vic26:11 (blue) are unpublished sequences determined in our laboratory (Xavier, 2015). The OW begomoviruses African cassava mosaic virus (ACMV), East African cassava mosaic virus (EACMV), Tomato yellow leaf curl virus (TYLCV) and Watermelon chlorotic stunt virus (WmCSV) were used as outgroups. Nodes with posterior probability values between 0.50 and 0.89 are indicated by empty circles and those with values equal to or greater than 0.90 are indicated by filled circles. 


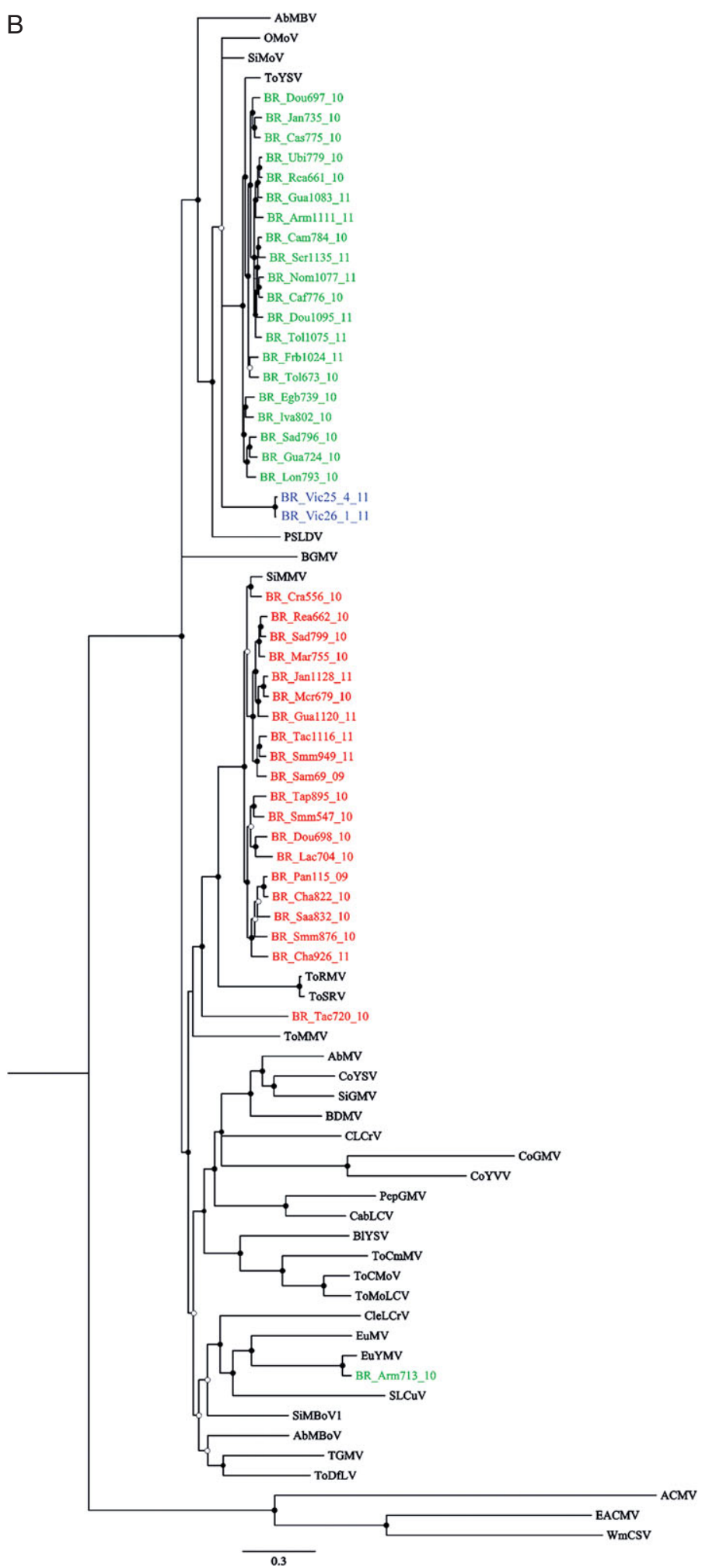

Figure 1 Continued 
Table 2 Recombination events detected in the Sida bright yellow mosaic virus (SiBYMV-BR:Tac720:10) and Sida golden yellow spot virus (SiGYSV -BR:Sab889:10) genomes, based on a data set including the nucleotide sequences of the begomoviruses described in this study and additional begomoviruses from the New World (NW) and Old World (OW)

\begin{tabular}{|c|c|c|c|c|c|c|c|}
\hline \multirow[b]{2}{*}{ Event } & \multirow[b]{2}{*}{ Recombinant } & \multicolumn{2}{|c|}{ Recombination Breakpoints ${ }^{\mathrm{b}}$} & \multicolumn{2}{|l|}{ Parents } & \multirow[b]{2}{*}{ Methodc } & \multirow[b]{2}{*}{$P$-value ${ }^{\mathrm{d}}$} \\
\hline & & Begin & End & Minor & Major & & \\
\hline & SiGYSVa (DNA-A) & & & & & & \\
\hline 1 & BR:Sab889:10 & 180 & 1178 & Unknown & SiMBoV1 (HM585441) & $\mathbf{R G B M C S 3}$ & $5.066 \times 10^{-38}$ \\
\hline 2 & $\begin{array}{l}\text { BR:Sab889:10 } \\
\text { SiBYMV (DNA-A) }\end{array}$ & 1448 & 1889 & SiYLCV (KC706539) & Unknown & RMC3 & $2.524 \times 10^{-7}$ \\
\hline 3 & $\begin{array}{l}\text { BR:Tac720:10 } \\
\text { SiBYMV (DNA-B) }\end{array}$ & 193 & 1906 & Unknown & SiMMV (FN436003) & RGBMCS3 & $7.891 \times 10^{-28}$ \\
\hline 4 & BR:Tac720:10 & 2562 & 587 & BR:Tol1075:11 & BDMV (M88180) & RBMCS & $1.725 \times 10^{-6}$ \\
\hline
\end{tabular}

a See Table S1 for the complete data set and full virus names.

becombination breakpoint coordinates are according to the first nucleotide after the cleavage site at the origin of replication, increasing clockwise.

${ }^{\mathrm{C}}$ Recombination events and their putative parental viruses were identified using the Rdp (R), Geneconv (G), Boostcan (B), Maxichi (M), Chimaera (C), Siscan (S) and 3Seq (3) modules in RDP4.

d The reported $P$-values are for the programs indicated in bold in the 'Method' column and are the lowest $P$-values calculated for the region in question.

A DNA-A component (BR:Sab889:10) was cloned from the Sida spp. sample \#889 (Table 1; a DNA-B was detected in sample \#889 but has not yet been cloned). Pairwise comparisons indicated the highest nt sequence identities of $72.1 \%$ with Tomato mottle leaf curl virus (ToMoLCV, JF803249) and $73.8 \%$ with two unpublished sequences obtained from Sida acuta samples in our laboratory (BR:Vic25.4:11 and BR:Vic26.1:11; Xavier, 2015). Thus, BR:Sab889:10 constitutes the third new virus species detected in the Sida spp. samples, for which the name Sida golden yellow spot virus (SiGYSV) is proposed.

Strikingly, the DNA-A components of BR:Sab889:10, BR:Vic25.4:11 and BR:Vic26.1:11 have a length within the range of OW begomoviruses (2813, 2828 and 2828 $\mathrm{nt}$, respectively) and contain an av2-like gene (which is present only in OW begomoviruses). The region encompassing part of the CR and the av2-like and $c p$ genes of these three components (approximately $1100 \mathrm{nt}$ ) has very low similarity to any other begomovirus. The deduced amino acid sequences of their CP and AV2-like proteins were further analysed with BLASTp and with the program Interpro. The analysis performed with Interpro indicated the presence of a domain related to geminivirus CPs, despite the divergence of the $c p$ gene (data not shown). No functional domains were predicted in the AV2-like protein. BLASTp analysis with the CP and AV2 proteins detected only a very low similarity with a highly divergent monopartite geminivirus recently described in China infecting apple trees, named 'apple geminivirus' (AGV) (Liang et al., 2015). The BR:Sab889:10 CP shares 27\% amino acid (aa) identity ( $90 \%$ coverage, $E$ value $2 \mathrm{e}^{-12}$ ) with the AGV CP and the AV2-like protein shares $43 \%$ aa identity $\left(83 \%\right.$ coverage, $E$ value $\left.1 \mathrm{e}^{-15}\right)$ with the putative $\mathrm{V} 2$ protein of $\mathrm{AGV}$.
Analysis with the RDP4 program detected two strongly supported recombination events in BR:Sab889:10, with Sida yellow leaf curl virus (SiYLCV, KC706539), Sida mosaic Bolivia virus 1 (SiMBoV1, HM585441) and two unknown viruses identified as putative parents (Table 2). In the phylogenetic tree, SiGYSV was placed in a cluster with BR:Vic25.4:11, BR:Vic26.1:11 and ToMoLCV (Fig. 1A), which is consistent with the pairwise identity analysis. A $c p$ nt sequence tree was constructed with a data set including four highly divergent geminiviruses (Citrus chlorotic dwarf-associated virus, CCDaV; Euphorbia caput-medusae latent virus, EcmLV; Grapevine red blotch associated virus, GRBaV; apple geminivirus, AGV), one topocuvirus (Tomato pseudo-curly top virus, TPCTV), BR:Vic25.4:11 and BR:Vic26.1:11, and seven NW and OW begomoviruses (Fig. 2). BR:Sab889:10 clusters with BR:Vic25.4:11, BR:Vic26.1:11 and AGV, reflecting the BLASTp analysis in which a similarity was found among the CPs of these four viruses. Studies are in progress in our laboratory to characterise these divergent, OW-like begomovirus species.

The vast majority of the DNA-A clones obtained from L. sibiricus samples corresponded to Tomato yellow spot virus (ToYSV) isolates (15 out of 16 DNA-A clones and 19 out of 20 DNA-B clones; Table 1). Pairwise sequence comparisons indicated that the DNA-A sequences share $>93.4 \%$ nt sequence identity with each other and $92.3 \%$ to $95.5 \%$ nt identity with the sequence of ToYSV (DQ336350), and the DNA-B sequences share $>91.9 \%$ nt identity amongst themselves and $91.0 \%$ to $92.3 \%$ nt identity with ToYSV (DQ336351) (Table 1; Fig. S1). The Bayesian phylogenetics trees based on the DNA-A and DNA-B components placed these isolates in clusters with ToYSV (Fig. 1).

The cloned DNA-A and DNA-B (BR:Arm713:10) from L. sibiricus sample \#713 have $97.2 \%$ and $95.3 \%$ 


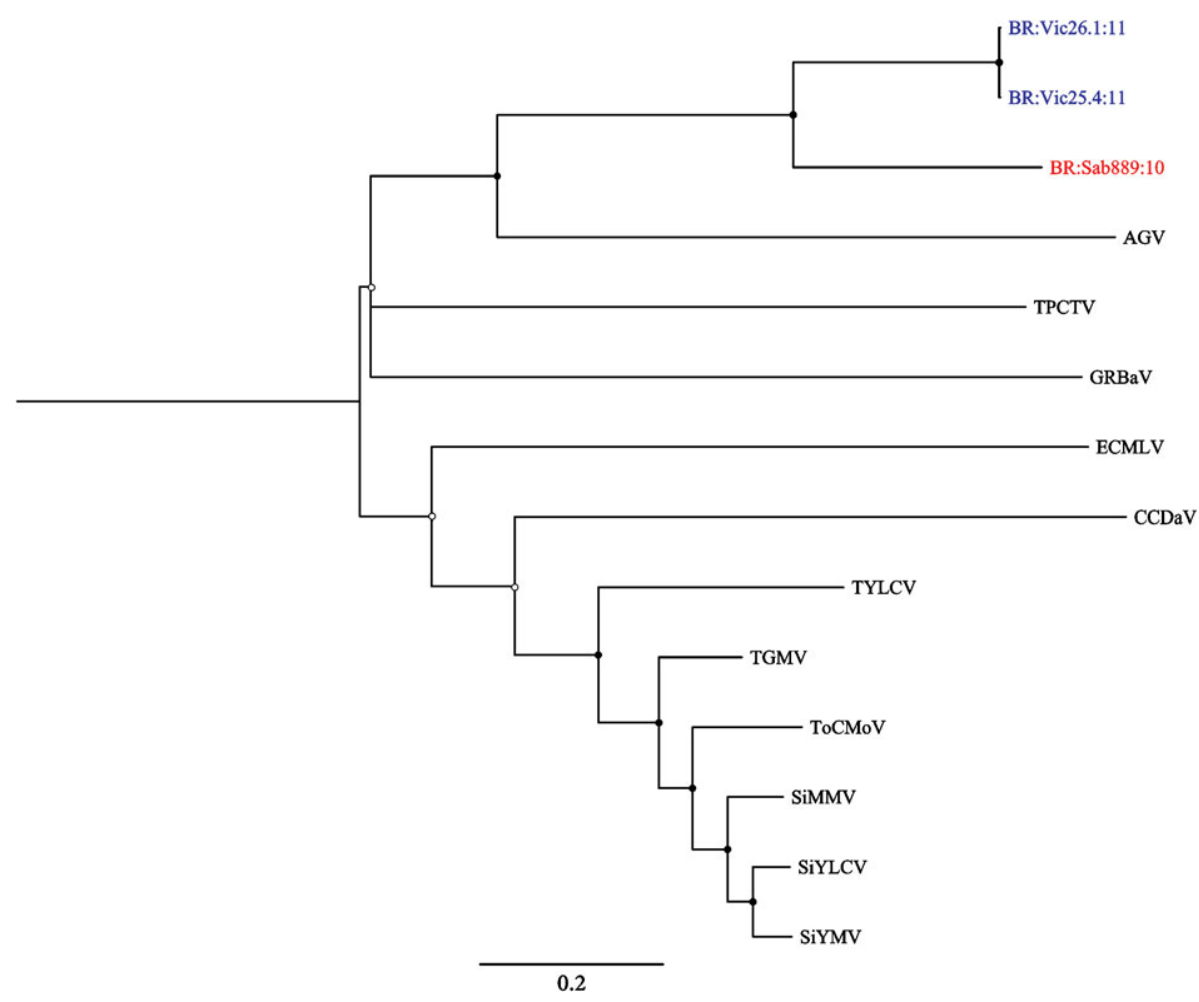

Figure 2 Bayesian phylogenetic tree based on the nucleotide sequences of the cp genes of Sida golden yellow spot virus (SiGYSV, in red and selected geminiviruses). The unrooted $c p$ tree includes four highly divergent geminiviruses (apple geminivirus, AGV; citrus chlorotic dwarf associated virus, CCDaV; Euphorbia caput-medusae latent virus, ECMLV; and grapevine red-blotch associated virus, GRBaV), one topocuvirus (Tomato pseudo-curly top virus, TPCTV), the BR:Vic25.4:11 and BR:Vic26:11 sequences (blue) determined in our laboratory, in addition to seven New World and Old World begomoviruses (see Table S1 for full names and GenBank access numbers). Nodes with posterior probability values between 0.60 and 0.89 are indicated by empty circles and those with values equal to or greater than 0.90 are indicated by filled circles.

nt sequence identity with EuYMV (FJ619507 and FJ619508), respectively (Table 1; Fig. S1). EuYMV has been found sporadically in some non-cultivated hosts (Fernandes et al., 2011; Silva et al., 2012; Tavares et al., 2012; Barreto et al., 2013; Rocha et al., 2013), but to our knowledge, this is the first report of EuYMV infecting plants of the genus Leonurus.

Alphasatellite DNA molecules were cloned from samples \#18 and \#1095 (Sida spp. and L. sibiricus, respectively; Table 1). Isolate BR:Chal 8:09 (1338 nt) showed the highest nt sequence identity (93.2\%) to Euphorbia yellow mosaic alphasatellite (EuYMA, FN436008) (Fig. S4) and a close phylogenetic relationship with this isolate (Fig. 3).

From sample \#1095, five alphasatellite clones (BR:Dou 1095.1:11 to BR:Dou 1095.5:11; all $1367 \mathrm{nt}$ ) as well as begomovirus DNA-A and DNA-B components were cloned (Table 1). Pairwise nt sequence comparisons indicated that the DNA-A and DNA-B sequences showed the highest identities with ToYSV (94.6\% and 93.0\%, respectively; Fig. S1). Alphassatellite sequences shared $>99.9 \%$ nt identity amongst themselves and $82.3 \%$ to
$82.4 \%$ nt identity with the sequence of EuYMA (Fig. S4). The sequences showed typical features of alphasatellite molecules, containing one ORF (alpha-Rep) potentially encoding a Rep protein with 313 amino acids (data not shown). The deduced amino acid sequences of the ORF display $86.9 \%$ identity with the Cleome leaf crumple alphasatellite (ClLCrA) alpha-Rep protein. The sequences also contain an A-rich region located immediately downstream of the ORF (coordinates 1115-1222, with a $57 \%$ adenine content) and a predicted hairpin structure containing, within the loop, the nonanucleotide TAGTATTAC, which is conserved in alphasatellites (Zhou, 2013).

Phylogenetic analysis showed that the isolates grouped most closely with EuYMA (Fig. 3), consistent with the pairwise identity analysis. According to the proposed demarcation threshold of $83 \%$ nt sequence identity for alphasatellites (Mubin et al., 2009, 2012), the five clones from $L$. sibiricus sample \#1095 represent a distinct alphasatellite, for which the name Leonurus yellow spot alphasatellite (LeYSA) is proposed. 


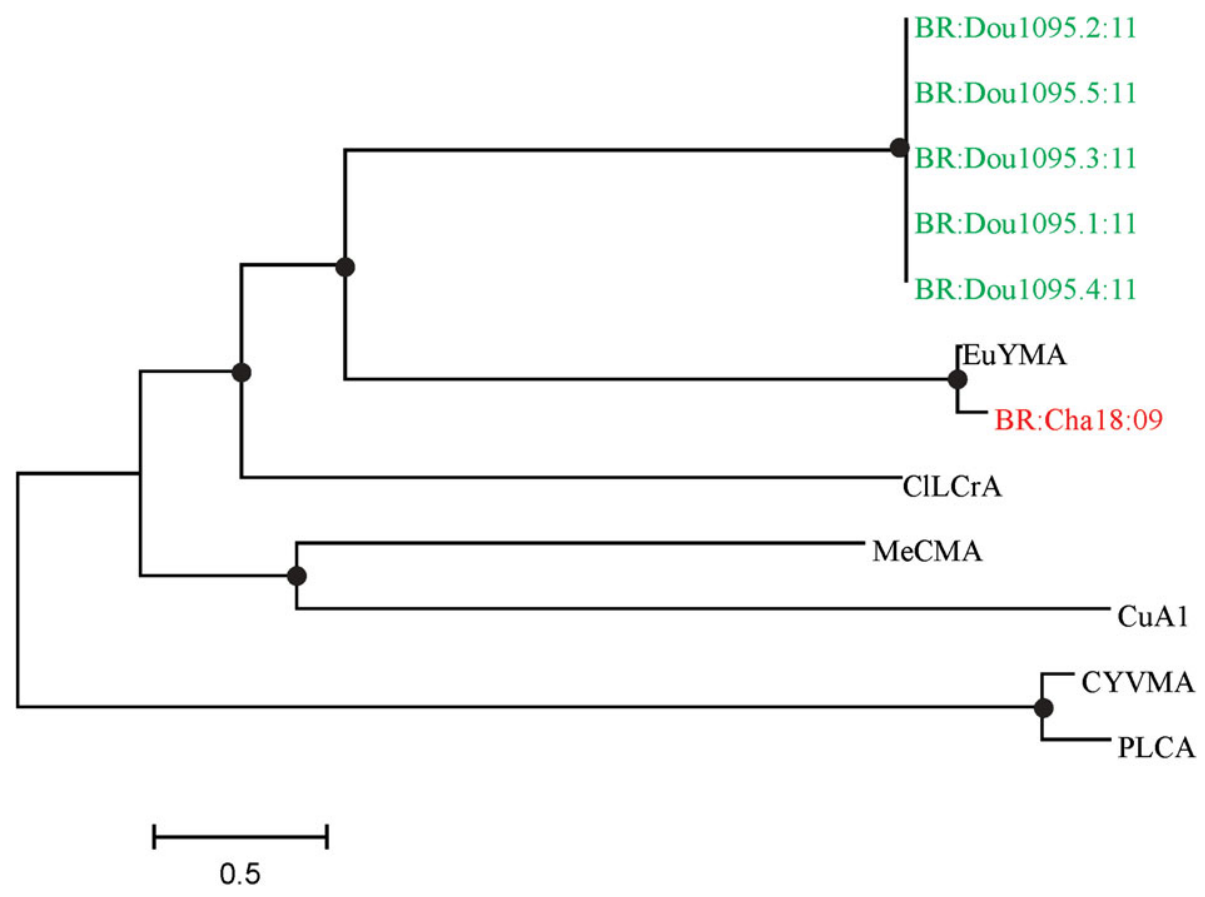

Figure 3 Bayesian phylogenetic tree based on the alphasatellites sequences described in this study from Sida spp. (red) and Leonurus sibiricus plants (green) and the most closely related alphasatellites (see Table S2 for full names and GenBank access numbers). Nodes with posterior probability values between 0.50 and 0.89 are indicated by empty circles and those with values equal to or greater than 0.90 are indicated by filled circles.

Originally thought to be restricted to the OW, alphasatellites have recently been found in association with bipartite begomoviruses in Brazil (state of Mato Grosso do Sul), Cuba and Venezuela (Paprotka et al., 2010; Romay et al., 2010; Jeske et al., 2014). Our results extend the geographical range of alphasatellites in South America, suggesting that these molecules may be widespread in the continent, and also their host range, with the first report of EuYMA infecting plants of the genus Sida and the detection of a new alphasatellite, LeYSA, in L. sibiricus.

Sida spp. are arguably the most abundant natural reservoirs for begomoviruses in several regions of the world (Frischmuth et al., 1997; Hofer et al., 1997; Roye et al., 1997; Echemendía et al., 2004; Jovel et al., 2004; Xiong et al., 2005; Guo \& Zhou, 2006; Das et al., 2008; Fiallo-Olivé et al., 2010; Fiallo-Olivé et al., 2012). For example, in a recent survey, Tavares et al. (2012) reported the occurrence of nine begomoviruses (including four new species) in 57 Sida spp. samples collected in the Brazilian states of Minas Gerais and Alagoas. Here, out of 43 Sida spp. samples, we found two previously described begomoviruses, three new species, and also (for the first time) an alphasatellite, further emphasising the tremendous diversity of begomoviruses and associated DNA satellites naturally infecting Sida spp.
Conversely, L. sibiricus harbours a much lower diversity of begomoviruses, with ToYSV as the causative agent of infection in almost all samples, corroborating with published data (Fernandes et al., 2014). ToYSV was first reported infecting tomato plants in the state of Minas Gerais (Ambrozevicius et al., 2002), and was later reported in bean and soybean plants in northwestern Argentina (Rodríguez-Pardina et al., 2011). L. sibiricus is a widely distributed plant in Brazil, and seems to be the main natural reservoir, as well as a potential source of inoculum, of ToYSV to bean, soybean and tomato crops, as previously noted also by Barbosa et al. (2012).

\section{Acknowledgements}

This work was funded by grants from CNPq (483607/ 2013-4) and Fapemig (CAG-APQ-02037-13) to F.M.Z. C. G. F. was the recipient of a CNPq doctoral fellowship. The authors wish to thank Elvira Fiallo-Olivé, Eduardo S.G. Mizubuti and Jesus Navas-Castillo for helpful discussions.

\section{References}

Alabi O.J., Ogbe F.O., Bandyopadhyay R., Kumar P.L., Dixon A.G.O., Hughes J.D., Naidu R.A. (2008) Alternate hosts of African cassava mosaic virus and East African cassava 
mosaic Cameroon virus in Nigeria. Archives of Virology, 153, $1743-1747$.

Albuquerque L.C., Varsani A., Fernandes F.R., Pinheiro B., Martin D.P., Oliveira Ferreira P.D.T., Lemos T.O., Inoue-Nagata A.K. (2012) Further characterization of tomato-infecting begomoviruses in Brazil. Archives of Virology, 157, 747-752.

Amarakoon I.I., Roye M.E., Briddon R.W., Bedford I.D., Stanley J. (2008) Molecular and biological characterization of Macroptilium yellow mosaic virus from Jamaica. Plant Pathology, 57, 417-426.

Ambrozevicius L.P., Calegario R.F., Fontes E.P.B., Carvalho M.G., Zerbini F.M. (2002) Genetic diversity of begomoviruses infecting tomato and associated weeds in Southeastern Brazil. Fitopatologia Brasileira, 27, 372-377.

Arnaud L.S.E.P., Santos C.D.G., Lima J.A.A., Feitosa F.A.A. (2007) Predominance of begomoviruses in tomatoes in the region of Serra de Ibiapaba, Ceará state, and their detection in weeds (in Portuguese). Fitopatologia Brasileira, 32, 241-246.

Assunção I.P., Listik A.F., Barros M.C.S., Amorim E.P.R., Silva S.J.C., Izael O.S., Ramalho-Neto C.E., Lima G.S.A. (2006) Genetic diversity of begomoviruses in invasive species of Northeastern Brazil (in Portuguese). Planta Daninha, 24, 239-244.

Barbosa J.C., Barreto S.S., Inoue-Nagata A.K., Reis M.S., Firmino A.C., Bergamin A., Rezende J.A.M. (2009) Natural infection of Nicandra physaloides by Tomato severe rugose virus in Brazil. Journal of General Plant Pathology, 75, 440-443.

Barbosa J.C., Eckstein B., Bergamin-Filho A., Rezende J.A.M., Dallagnol L.J. (2012) First report of Tomato yellow spot virus infecting Leonurus sibiricus in Brazil. Plant Disease, 97, 289-298.

Barreto S.S., Hallwass M., Aquino O.M., Inoue-Nagata A.K. (2013) A study of weeds as potential inoculum sources for a tomato-infecting begomovirus in central Brazil. Phytopathology, 103, 436-444.

Basso M.F., Silva J.C., Fajardo T.V., Fontes E.P., Zerbini F.M. (2015) A novel, highly divergent ssDNA virus identified in Brazil infecting apple, pear and grapevine. Virus Research, 210, 27-33.

Berrie L.C., Rybicki E.P., Rey M.E.C. (2001) Complete nucleotide sequence and host range of South African cassava mosaic virus: further evidence for recombination amongst begomoviruses. Journal of General Virology, 82, 53-58.

Briddon R.W., Akbar F., Iqbal Z., Amrao L., Amin I., Saeed M., Mansoor M.S. (2014) Effects of genetic changes to the begomovirus/betasatellite complex causing cotton leaf curl disease in South Asia post-resistance breaking. Virus Research, 186, 114-119.

Brown J.K., Fauquet C.M., Briddon R.W., Zerbini F.M., Moriones E., Navas-Castillo J. (2012) Family Geminiviridae. In Virus Taxonomy. Ninth Report of the International Committee on Taxonomy of Viruses, pp. 351-373. Eds A.M.Q. King, M.J.
Adams, E.B. Carstens and E.J. Lefkowitz. London, UK: Elsevier Academic Press.

Brown J.K., Zerbini F.M., Navas-Castillo J., Moriones E., Ramos-Sobrinho R., Silva J.C.F., Fiallo-Olivé E., Briddon R.W., Hernández-Zepeda C., Idris A., Malathi V.G., Martin D.P., Rivera-Bustamante R., Ueda S., Varsani A. (2015) Revision of Begomovirus taxonomy based on pairwise sequence comparisons. Archives of Virology, 160, $1593-1619$.

Brustolini O.J.B., Machado J.P.B., Condori-Apfata J.A., Coco D., Deguchi M., Loriato V.A.P., Pereira W.A., Alfenas-Zerbini P., Zerbini F.M., Inoue-Nagata A.K., Santos A.A., Chory J., Silva F.F., Fontes E.P.B. (2015) Sustained NIK-mediated antiviral signalling confers broad-spectrum tolerance to begomoviruses in cultivated plants. Plant Biotechnology Journal, 13, 1300-1311.

Calegario R.F., Ferreira S.S., Andrade E.C., Zerbini F.M. (2007) Characterization of Tomato yellow spot virus, a novel tomato-infecting begomovirus in Brazil. Pesquisa Agropecuária Brasileira, 42, 1335-1343.

Castillo-Urquiza G.P., Beserra Junior J.E.A., Alfenas-Zerbini P., Varsani A., Lima A.T.M., Barros D.R., Zerbini F.M. (2007) Genetic diversity of begomoviruses infecting tomato in Paty do Alferes, Rio de Janeiro state, Brazil. Virus Reviews and Research, 12, 233.

Castillo-Urquiza G.P., Beserra J.E.A. Jr., Bruckner F.P., Lima A.T.M., Varsani A., Alfenas-Zerbini P., Zerbini F.M. (2008) Six novel begomoviruses infecting tomato and associated weeds in Southeastern Brazil. Archives of Virology, 153, 1985-1989.

Costa A.S. (1955) Studies on Abutilon mosaic in Brazil. Phytopathologische Zeitschrift, 24, 97-112.

Costa A.S., Bennett C.W. (1950) Whitefly transmitted mosaic of Euphorbia prunifolia. Phytopathology, 40, 266-283.

Cotrim M.A., Krause-Sakate R., Narita N., Zerbini F.M., Pavan M.A. (2007) Genetic diversity ot tomato-infecting begomoviruses in Central São Paulo state (in Portuguese). Summa Phytopathologica, 33, 300-303.

Das S., Paul S., Ghosh R., Palit P., Acharyya S., Das A., Mir J.I., Ghosh S.K., Roy A. (2008) Occurrence of a begomovirus and satellite DNA associated with yellow vein disease of Sida sp. from eastern India and its computational analyses. Indian Journal of Virology, 19, 119-119.

Doyle J.J., Doyle J.L. (1987) A rapid DNA isolation procedure for small amounts of fresh leaf tissue. Phytochemical Bulletin, $19,11-15$.

Echemendía A.L., Ramos P.L., Díaz L., Peral R., Fuentes A., Pujol M., González G. (2004) First report of Sida golden yellow vein virus infecting Sida species in Cuba. Plant Pathology, 53, 234.

Edgar R.C. (2004) MUSCLE: a multiple sequence alignment method with reduced time and space complexity. BMC Bioinformatics, 5, 1-19. 
Faria J.C., Maxwell D.P. (1999) Variability in geminivirus isolates associated with Phaseolus spp. in Brazil. Phytopathology, 89, 262-268.

Faria J.C., Bezerra I.C., Zerbini F.M., Ribeiro S.G., Lima M.F. (2000) Current status of geminivirus diseases in Brazil (in Portuguese). Fitopatologia Brasileira, 25, 125-137.

Fernandes A.V., Galvão R.M., Machado J.J., Zerbini F.M., Fontes E.P.B. (1999) Cloning and molecular characterization of A components of two new Sida rhombifolia-infecting geminiviruses. Virus Reviews and Research, 4, 148.

Fernandes J.J., Carvalho M.G., Andrade E.C., Brommonschenkel S.H., Fontes E.P.B., Zerbini F.M. (2006) Biological and molecular properties of Tomato rugose mosaic virus (ToRMV), a new tomato-infecting begomovirus from Brazil. Plant Pathology, 55, 513-522.

Fernandes F.R., Albuquerque L.C., Giordano L.B., Boiteux L.S., Ávila A.C., Inoue-Nagata A.K. (2008) Diversity and prevalence of Brazilian bipartite begomovirus species associated to tomatoes. Virus Genes, 36, 251-258.

Fernandes F.R., Albuquerque L.C., Oliveira C.L., Cruz A.R.R., Rocha W.B., Pereira T.G., Naito F.Y.B., Dias N.D., Nagata T., Faria J.C., Zerbini F.M., Aragão F.J.L., Inoue-Nagata A.K. (2011) Molecular and biological characterization of a new Brazilian begomovirus, euphorbia yellow mosaic virus (EuYMV), infecting Euphorbia heterophylla plants. Archives of Virology, 156, 2063-2069.

Fernandes N.A.N., Boiteux L.S., Fonseca M.E.N., GonzalesSegnana L., Kitajima E.W. (2014) Report of Tomato yellow spot virus infecting Leonurus sibiricus in Paraguay and within tomato fields in Brazil. Plant Disease, 98, 1445.

Fiallo-Olivé E., Martinez-Zubiaur Y., Moriones E., NavasCastillo J. (2010) Complete nucleotide sequence of Sida golden mosaic Florida virus and phylogenetic relationships with other begomoviruses infecting malvaceous weeds in the Caribbean. Archives of Virology, 155, 1535-1537.

Fiallo-Olivé E., Navas-Castillo J., Moriones E., MartinezZubiaur Y. (2012) Begomoviruses infecting weeds in Cuba: increased host range and a novel virus infecting Sida rhombifolia. Archives of Virology, 157, 141-146.

Frischmuth T., Engel M., Lauster S., Jeske H. (1997) Nucleotide sequence evidence for the occurrence of three distinct whitefly-transmitted, Sida-infecting bipartite geminiviruses in Central America. Journal of General Virology, 78, 2675-2682.

García-Andrés S., Monci F., Navas-Castillo J., Moriones E. (2006) Begomovirus genetic diversity in the native plant reservoir Solanum nigrum: evidence for the presence of a new virus species of recombinant nature. Virology, 350, 433-442.

García-Andrés S., Accotto G.P., Navas-Castillo J., Moriones E. (2007a) Founder effect, plant host, and recombination shape the emergent population of begomoviruses that cause the tomato yellow leaf curl disease in the Mediterranean basin. Virology, 359, 302-312.
García-Andrés S., Tomas D.M., Sanchez-Campos S., NavasCastillo J., Moriones E. (2007b) Frequent occurrence of recombinants in mixed infections of tomato yellow leaf curl disease-associated begomoviruses. Virology, 365, 210-219.

Glick E., Zrachya A., Levy Y., Mett A., Gidoni D., Belausov E., Citovsky V., Gafni Y. (2008) Interaction with host SGS3 is required for suppression of RNA silencing by tomato yellow leaf curl virus V2 protein. Proceedings of the National Academy of Sciences of the United States of America, 105, 157-161.

Guo X.J., Zhou X.P. (2006) Molecular characterization of a new begomovirus infecting Sida cordifolia and its associated satellite DNA molecules. Virus Genes, 33, 279-285.

Hanley-Bowdoin L., Bejarano E.R., Robertson D., Mansoor S. (2013) Geminiviruses: masters at redirecting and reprogramming plant processes. Nature Reviews. Microbiology, 11, $777-788$.

Harrison B.D., Robinson D.J. (1999) Natural genomic and antigenic variation in white-fly transmitted geminiviruses (begomoviruses). Annual Review of Phytopathology, 39, 369-398.

Hofer P., Engel M., Jeske H., Frischmuth T. (1997) Nucleotide sequence of a new bipartite geminivirus isolated from the common weed Sida rhombifolia in Costa Rica. Virology, 78, $1785-1790$.

Idris A.M., Brown J.K. (2002) Molecular analysis of cotton leaf curl virus-Sudan reveals an evolutionary history of recombination. Virus Genes, 24, 249-256.

Idris A.M., Hiebert E., Bird J., Brown J.K. (2003) Two newly described begomoviruses of Macroptilium lathyroides and common bean. Phytopathology, 93, 774-783.

Inoue-Nagata A.K., Albuquerque L.C., Rocha W.B., Nagata T. (2004) A simple method for cloning the complete begomovirus genome using the bacteriophage phi 29 DNA polymerase. Journal of Virological Methods, 116, 209-211.

Jeske H., Kober S., Schäfer B., Strohmeier S. (2014) Circomics of Cuban geminiviruses reveals the first alphasatellite DNA in the Caribbean. Virus Genes, 49, 312-324.

Jovel J., Reski G., Rothenstein D., Ringel M., Frischmuth T., Jeske H. (2004) Sida micrantha mosaic is associated with a complex infection of begomoviruses different from Abutilon mosaic virus. Archives of Virology, 149, 829-841.

Krenz B., Thompson J.R., Fuchs M., Perry K.L. (2012) Complete genome sequence of a new circular DNA virus from grapevine. Journal of Virology, 86, 7715.

Lefeuvre P., Lett J.M., Varsani A., Martin D.P. (2009) Widely conserved recombination patterns among single-stranded DNA viruses. Journal of Virology, 83, 2697-2707.

Liang P., Navarro B., Zhang Z., Wang H., Lu M., Xiao H., Wu Q., Zhou X., Di Serio F., Li S. (2015) Identification and characterization of a novel geminivirus with monopartite genome infecting apple trees. Journal of General Virology, 96, $2411-2420$. 
Loconsole G., Saldarelli P., Doddapaneni H., Savino V., Martelli G.P., Saponari M. (2012) Identification of a singlestranded DNA virus associated with citrus chlorotic dwarf disease, a new member in the family Geminiviridae. Virology, 432, 162-172.

Mahajan N., Parameswari C., Veluthambi K. (2011) Severe stunting in blackgram caused by the Mungbean yellow mosaic virus (MYMV) KA27 DNA B component is ameliorated by co-infection or post-infection with the KA22 DNA $\mathrm{B}$ : MYMV nuclear shuttle protein is the symptom determinant. Virus Research, 157, 25-34.

Mansoor S., Briddon R.W., Zafar Y., Stanley J. (2003) Geminivirus disease complexes: an emerging threat. Trends in Plant Science, 8, 128-134.

Márquez-Martín B., Aragón-Caballero L., Fiallo-Olivé E., Navas-Castillo J., Moriones E. (2011) Tomato leaf deformation virus, a novel begomovirus associated with a severe disease of tomato in Peru. European Journal of Plant Pathology, 129, 1-7.

Martin D.P., Lemey P., Lott M., Moulton V., Posada D., Lefeuvre P. (2010) RDP3: a flexible and fast computer program for analyzing recombination. Bioinformatics, 26, 2462-2463.

Medina C.G.V., Lambertini P.M.L. (2012) Tomato dwarf leaf virus, a New World begomovirus infecting tomato in Argentina. Archives of Virology, 157, 1975-1980.

Melgarejo T.A., Kon T., Rojas M.R., Paz-Carrasco L., Zerbini F.M., Gilbertson R.L. (2013) Characterization of a New World monopartite begomovirus causing leaf curl disease of tomato in Ecuador and Peru reveals a new direction in geminivirus evolution. Journal of Virology, 87, 5397-5413.

Monci F., Sanchez-Campos S., Navas-Castillo J., Moriones E. (2002) A natural recombinant between the geminiviruses Tomato yellow leaf curl Sardinia virus and Tomato yellow leaf curl virus exhibits a novel pathogenic phenotype and is becoming prevalent in Spanish populations. Virology, 303, 317-326.

Monde G., Walangululu J., Winter S., Bragard C. (2010) Dual infection by cassava begomoviruses in two leguminous species (Fabaceae) in Yangambi, Northeastern Democratic Republic of Congo. Archives of Virology, 155, 1865-1869.

Mubin M., Briddon R.W., Mansoor S. (2009) Diverse and recombinant DNA betasatellites are associated with a begomovirus disease complex of Digera arvensis, a weed host. Virus Research, 142, 208-212.

Mubin M., Akhtar S., Amin I., Briddon R.W., Mansoor S. (2012) Xanthium strumarium: a weed host of components of begomovirus-betasatellite complexes affecting crops. Virus Genes, 44, 112-119.

Muhire B.M., Varsani A., Martin D.P. (2014) SDT: a virus classification tool based on pairwise sequence alignment and identity calculation. PLOS ONE, 9, e108277.
Nylander J.A.A. (2004) MrModeltest v2. In Program distributed by the author. Evolutionary Biology Centre, Uppsala University.

Padidam M., Beachy R.N., Fauquet C.M. (1996) The role of AV2 ("precoat") and coat protein in viral replication and movement in tomato leaf curl geminivirus. Virology, 224, 390-404.

Padidam M., Sawyer S., Fauquet C.M. (1999) Possible emergence of new geminiviruses by frequent recombination. Virology, 265, 218-224

Paprotka T., Metzler V., Jeske H. (2010) The first DNA 1-like alpha satellites in association with New World begomoviruses in natural infections. Virology, 404, 148157.

Paximadis M., Idris A.M., Torres-Jerez I., Villarreal A., Rey M.E.C., Brown J.K. (1999) Characterization of tobacco geminiviruses in the Old and New World. Archives of Virology, 144, 703-717.

Pita J.S., Fondong V.N., Sangare A., Otim-Nape G.W., Ogwal S., Fauquet C.M. (2001) Recombination, pseudorecombination and synergism of geminiviruses are determinant keys to the epidemic of severe cassava mosaic disease in Uganda. Journal of General Virology, 82, 655-665.

Ramos-Sobrinho R., Xavier C.A.D., Pereira H.M.D.B., Lima G.S.D.A., Assunção I.P., Mizubuti E.S.G., Duffy S., Zerbini F.M. (2014) Contrasting genetic structure between two begomoviruses infecting the same leguminous hosts. Journal of General Virology, 95, 2540-2552.

Ribeiro S.G., Ambrozevicius L.P., Ávila A.C., Bezerra I.C., Calegario R.F., Fernandes J.J., Lima M.F., Mello R.N., Rocha H., Zerbini F.M. (2003) Distribution and genetic diversity of tomato-infecting begomoviruses in Brazil. Archives of Virology, 148, 281-295.

Ribeiro S.G., Martin D.P., Lacorte C., Simões I.C., Orlandini D.R.S., Inoue-Nagata A.K. (2007) Molecular and biological characterization of Tomato chlorotic mottle virus suggests that recombination underlies the evolution and diversity of Brazilian tomato begomoviruses. Phytopathology, 97, 702-711.

Rocha C.S., Castillo-Urquiza G.P., Lima A.T.M., Silva F.N., Xavier C.A.D., Hora-Junior B.T., Beserra-Junior J.E.A., Malta A.W.O., Martin D.P., Varsani A., Alfenas-Zerbini P., Mizubuti E.S.G., Zerbini F.M. (2013) Brazilian begomovirus populations are highly recombinant, rapidly evolving, and segregated based on geographical location. Journal of Virology, 87, 5784-5799.

Rodríguez-Pardina P.E., Hanada K., Laguna I.G., Zerbini F.M., Ducasse D.A. (2011) Molecular characterisation and relative incidence of bean- and soybean-infecting begomoviruses in northwestern Argentina. Annals of Applied Biology, 158, 69-78.

Rojas M.R., Hagen C., Lucas W.J., Gilbertson R.L. (2005) Exploiting chinks in the plant's armor: evolution and emergence of geminiviruses. Annual Review of Phytopathology, 43, 361-394. 
Romay G., Chirinos D., Geraud-Pouey F., Desbiez C. (2010) Association of an atypical alphasatellite with a bipartite New World begomovirus. Archives of Virology, 155, 1843-1847.

Ronquist F., Huelsenbeck J.P. (2003) MrBayes 3: Bayesian phylogenetic inference under mixed models. Bioinformatics, 19, 1572-1574.

Roye M.E., McLaughlin W.A., Nakhla M.K., Maxwell D.P. (1997) Genetic diversity among geminiviruses associated with the weed species Sida spp., Macroptilium lathyroides, and Wissadula amplissima from Jamaica. Plant Disease, 81, $1251-1258$

Rybicki E.P. (1994) A phylogenetic and evolutionary justification for three genera of Geminiviridae. Archives of Virology, 139, 49-77.

Silva A.K.F., Santos C.D.G., Nascimento A.K.Q. (2010) Begomovirus transmission from weeds to tomato by the whitefly. Planta Daninha, 28, 507-514

Silva S.J.C., Castillo-Urquiza G.P., Hora-Júnior B.T., Assunção I.P., Lima G.S.A., Pio-Ribeiro G., Mizubuti E.S.G., Zerbini F.M. (2011) High genetic variability and recombination in a begomovirus population infecting the ubiquitous weed Cleome affinis in northeastern Brazil. Archives of Virology, 156, 2205-2213.

Silva S.J.C., Castillo-Urquiza G.P., Hora-Junior B.T., Assunção I.P., Lima G.S.A., Pio-Ribeiro G., Mizubuti E.S.G., Zerbini F.M. (2012) Species diversity, phylogeny and genetic variability of begomovirus populations infecting leguminous weeds in northeastern Brazil. Plant Pathology, 61, 457-467.

Tamura K., Stecher G., Peterson D., Filipski A., Kumar S. (2013) MEGA6: Molecular Evolutionary Genetics Analysis version 6.0. Molecular Biology and Evolution, 30, 2725-2729.

Tavares S.S., Ramos-Sobrinho R., Gonzalez-Aguilera J., Lima G.S.A., Assunção I.P., Zerbini F.M. (2012) Further molecular characterization of weed-associated begomoviruses in Brazil with an emphasis on Sida spp. Planta Daninha, 30, 305-315.

Varsani A., Navas-Castillo J., Moriones E., Hernández-Zepeda C., Idris A., Brown J.K., Zerbini F.M., Martin D.P. (2014) Establishment of three new genera in the family Geminiviridae: Becurtovirus, Eragrovirus and Turncurtovirus. Archives of Virology, 159, 2193-2203.

Xavier C.A.D. (2015) Species diversity and genetic variability of bipartite begomoviruses in the New World. M.Sc. Dissertation. Universidade Federal de Viçosa.

Xiong Q., Guo X.J., Che H.Y., Zhou X.P. (2005) Molecular characterization of a distinct Begomovirus and its associated satellite DNA molecule infecting Sida acuta in China. Journal of Phytopathology, 153, 264-268.

Zerbini F.M., Andrade E.C., Barros D.R., Ferreira S.S., Lima A.T.M., Alfenas P.F., Mello R.N. (2005) Traditional and novel strategies for geminivirus management in Brazil. Australasian Plant Pathology, 34, 475-480.
Zhou X. (2013) Advances in understanding begomovirus satellites. Annual Review of Phytopathology, 51, 357-381.

Zhou X., Liu Y., Calvert L., Munoz C., Otim-Nape G.W., Robinson D.J., Harrison B.D. (1997) Evidence that DNA-A of a geminivirus associated with severe cassava mosaic disease in Uganda has arisen by interspecific recombination. Journal of General Virology, 78, 2101-2111.

Zhou X., Liu Y., Robinson D.J., Harrison B.D. (1998) Four DNA-A variants among Pakistani isolates of cotton leaf curl virus and their affinities to DNA-A of geminivirus isolates from okra. Journal of General Virology, 79, 915-923.

\section{Supporting Information}

Additional Supporting Information may be found in the online version of this article:

Table S1. Geminivirus sequences used for pairwise sequence comparisons, phylogenetic analysis and detection of recombination events.

Table S2. Alphasatellite sequences used for pairwise sequence comparisons, phylogenetic analysis and detection of recombination events.

Fig. S1. Pairwise sequence identity matrices of the DNA-A (A) and DNA-B (B), between the begomoviruses obtained from Sida spp. (red) and Leonurus sibiricus plants (green) in this study and additional begomovirus from the Americas. BR:Vic25.4:11 and BR:Vic26:11 (blue) are unpublished sequences determined in our laboratory (Xavier, 2015).

Fig. S2. Bayesian phylogenetic trees based on the nucleotide sequences of the $c p$ (A) and rep (B) genes of the begomoviruses obtained from Sida spp. (red) and Leonurus sibiricus plants (green) in this study plus begomoviruses from the New World and Old World (see Table S1, Supporting Information, for full names and GenBank access numbers). BR:Vic25.4:11 and BR:Vic26:11 (blue) are unpublished sequences determined in our laboratory (Xavier, 2015). The OW begomoviruses African cassava mosaic virus (ACMV), East African cassava mosaic virus (EACMV), Tomato yellow leaf curl virus (TYLCV) and Watermelon chlorotic stunt virus (WmCSV) were used as outgroups. Nodes with posterior probability values between 0.50 and 0.89 are indicated by empty circles and those with values equal to or greater than 0.90 are indicated by filled circles.

Fig. S3. Bayesian phylogenetic trees based on the nucleotide sequences of the $m p$ (A) and $n s p$ (B) genes of the begomoviruses obtained from Sida spp. (red) and Leonurus sibiricus plants (green) in this study plus begomoviruses from the New World and Old World (see Table S1 for full names and GenBank access numbers). The OW begomoviruses African cassava mosaic virus (ACMV), East African cassava mosaic virus (EACMV) and Watermelon 
chlorotic stunt virus (WmCSV) were used as outgroups. Nodes with posterior probability values between 0.50 and 0.89 are indicated by empty circles and those with values equal to or greater than 0.90 are indicated by filled circles.
Figure S4. Pairwise sequence identity matrices between the alphasatellites sequences described in this study from Sida spp. (red) and Leonurus sibiricus plants (green) and the most closely related alphasatellites (see Table S2 for full names and GenBank access numbers). 